\title{
Variations in Mitochondrial DNA of Dogs Isolated from Archaeological Sites in Japan and Neighbouring Islands
}

\author{
Naohiko Okumura ${ }^{1}$, Naotaka Ishiguro ${ }^{2}$, Masuo Nakano $^{1}$, Akira Matsui ${ }^{3}$, \\ Nobuo Shigehara $^{4}$, Toyohiko Nishimoto ${ }^{5}$, and Makoto Sahara ${ }^{5}$ \\ 1 Department of Bioresource Chemistry, Obihiro University of Agriculture and Veterinary Medicine, Obihiro \\ 2 Department of Veterinary Public Health, Obihiro University of Agriculture and Veterinary Medicine, Obihiro \\ 3 Nara National Cultural Properties Research Institute, Nara \\ 4 Primate Research Institute, Kyoto University, Inuyama \\ 5 National Museum of Japanese History, Sakura
}

(Submitted March 3, 1999; Review sent May 25, 1999; Accepted July 29, 1999)

\begin{abstract}
Sequences of ancient mitochondrial DNA (mtDNA) from archaeological remains of Japanese dogs were determined from 145 ancient dog samples (mainly bones) from the Jomon (100C-4C B.C.), Yayoi (4C B.C. -3C A.D.), Kofun (3-6C A.D.), Okhotsk (7-12C A.D.) and the Kamakura (12-14C A.D.) Periods. Highly variable sequences of the mitochondrial control region (198 base pairs) were amplified at least twice from independently prepared DNA extracts, and those from ancient samples were compared with 28 haplotypes from 178 modern dogs. The 198-bp ancient mtDNA was amplified from 74 ancient dog samples, and the sequences were classified into 19 haplotypes comprising five modern haplotypes (M1, M2, M5, M10 and M11) identified in modern dogs and 14 ancient haplotypes showing unique sequences not observed in modern dogs. Haplotype M5 was widely distributed in archaeological sites in northern Japan and Sakhalin, while haplotype M2 was detected from archaeological sites in southern Japan. Three major clusters (CL1 to CL3) were distinguished within the modern dog control region using phylogenetic analysis; all ancient dogs belonged to the CL1 cluster. From these results, we could not discern which modern Japanese dog breed closely resembles ancient dogs using phylogenetic analysis, but the CL1 cluster was likely distributed in the Japanese archipelago from the Jomon Period.
\end{abstract}

Keywods: Ancient DNA, Dog, Haplotype, Mitochondria, PCR

Corresponding author: Naotaka Ishiguro

Dept. Vet. Pub. Hlth., Obihiro University of Agriculture and Veterinary Medicine

Obihiro, Hokkaido, 080-8555, Japan

TEL: +81-155-49-5391 FAX: +81-155-49-5402 E-mail: ishiguro@obihiro. ac.jp 


\section{Introduction}

The dog (Canis familiaris) is the oldest domesticated animal, and its ancestor is thought to have evolved from southern wolves inhabiting the Arabian Peninsula and South Asia (Scott and Fuller, 1965; Hemmer, 1990). Because dogs have a close relationship with humans, they would always have migrated with humans. Dogs have been domesticated by artificial selection and cross breeding for use as a hunting companion and for other work, or simply as attractive pets. Dogs have spread world-wide with humans, and sometimes have cross-bred with closely related species, such as the gray wolf (Hemmer, 1990; Clutton-Brock, 1995). The possible events of the selected breeding and cross-breeding of dogs with closely related species may be traced as an evolutionary genetic footprint within the nuclear and mitochondrial DNA (mtDNA). Tsuda and others (1997) compared the sequence of the mtDNA control region from 34 individual dogs of 24 breeds and from 19 individual wolves of 3 subspecies. They found two major clades that contained wolf and dog mtDNA haplotypes in the phylogenetic tree. Vilà and others (1997) analyzed the mtDNA control region sequences from 162 wolves at 27 localities worldwide and from 140 domestic dogs of 67 breeds. They found that the dog haplotypes belong to four distinct clades and that the dog haplotypes clustered with wolf haplotypes in two of the four dog clades, suggesting that genetic exchanges between dog and wolf populations occurred frequently.

Okumura and others (1996) showed that the mitochondrial DNA control region of 94 modern dogs has 38 different haplotypes, and that genetic variations exist not only within Japanese native dog breeds, but also between Japanese and non-Japanese dogs. These abundant genetic backgrounds are thought to reflect the complexity produced by gene flows from foreign dogs before the Japanese dog breeds of today were established. Six Japanese dog breeds (Hokkaido dog, Akita dog, Kai dog, Shiba dog, Kishu dog and Shikoku dog), and other varieties, are now preserved in Japan as indigenous breeds (Tanabe, 1991), and they are claimed to be descendants of the Japanese indigenous dogs of ancient times. How far back can these Japanese indigenous breeds be traced in archaeological specimens? What types of dogs existed in Japan in the prehistoric and early historical periods, and if the ancient dogs are related to the modern indigenous dog breed in Japan, when were these breeds established? These questions can be answered by investigating the morphological or genetic similarities between modern Japanese dog breeds and ancient dogs. To date, many ancient dog samples have been discovered from archaeological sites, especially from shell mounds where faunal remains are better preserved. Shigehara (1994) investigated the morphology of ancient dog bones, but little is known about their genetic background. Advances in DNA techniques in the field of ancient biology since the mid-1980s can now provide direct information about the phylogenetic relationships of extinct species (Higuchi and others, 1987; Thomas and others, 1989; Cooper and others, 1992) and population levels (Horai and others, 1991; Hagelberg and Clegg 1993; Stone and Stoneking 1993; Hardy and others, 1995; Oota and others, 1995). Using DNA techniques, Japanese ancient dogs may offer valuable 
information about the origin of modern Japanese dogs and the genetic alteration producing the sequence diversity of modern Japanese dogs.

In this study, we amplified the ancient mtDNA using the polymerase chain reaction (PCR) from the bones and teeth of ancient Japanese dogs, and we examined the DNA sequences. To estimate the genetic relationship with modern Japanese dog breeds, the ancient mtDNA sequences were compared with modern dog mtDNA lineages using phylogenetic analysis.

\section{Materials and Methods}

Modern dog samples

In addition to 94 modern dogs (73 Japanese native dogs and 21 non-Japanese dogs) reported by Okumura and others (1996), 48 Japanese native dogs and 36 non-Japanese dogs were newly examined in this study. The modern Japanese dog samples comprised six dog breeds native to the main island (Shiba, Hokkaido, Akita, Kai, Kishu and Shikoku) and two breeds indigenous to the Iki and Ryukyu islands (Iki and Ryukyu). Genomic DNA of all dog samples was isolated from peripheral blood leukocytes, the mtDNA control region was amplified using PCR, and the sequences were determined by direct sequencing using a 373S DNA Sequencer (Applied Biosystems Inc., Foster City, CA). The 198-bp of the mtDNA control region was used to construct the modern dog mtDNA data base and was compared with the corresponding region from ancient dog samples.

\section{Archaeological bone samples of Japanese ancient dogs}

A total of 145 well-preserved ancient dog specimens (73 mandibles, 16 femurs, 4 ulnas, 5 radii, 9 humeri, 11 tibiae and 27 tooth roots) were collected from 30 archaeological sites, many of them from shell mounds (Table 1).

Almost all the ancient specimens were from the archaeological sites of five historical periods: Jomon Period (about 100C-4C B.C.; 54 specimens), Yayoi Period (about 4C B.C.-3C A.D.; 34 specimens), Kofun Period (about 3C-6C A.D.; 1 specimen), and Kamakura Period (1192-1333 A.D.: 21 specimens) (Table 1). Thirty-five samples were from archaeological sites of the Okhotsk Period (7C to 12C A.D.) around the Sea of Okhotsk. The 25 ancient specimens from Susuya shell mound (Sakhalin), Musashi-wan site (Paramushir Island) and Sensyu-to site (Shumshu Island) were taken from Hasebe's dog collection made before World War II.

\section{DNA extraction}

All ancient DNA of the archaeological specimens was extracted from the bones or tooth roots. The soil and outer layers of the samples were removed by scraping with a sterile razor blade. The samples were powdered using an electric drill producing about 0.2 to $0.5 \mathrm{~g}$ of bone powder, which was then suspended in $10 \mathrm{ml}$ of $0.5 \mathrm{M}$ ethylenediamine tetraacetic acid (EDTA), decalcified by rotating for 30 minutes, and was centrifuged at 
Table 1 Sampling sites and haplotypes of ancient DNA sequences

\begin{tabular}{|c|c|c|c|c|}
\hline $\begin{array}{l}\text { Site } \\
\text { No. }\end{array}$ & $\begin{array}{l}\text { Archaeological sites } \\
\text { (Prefecture or island, Periods) }\end{array}$ & $\begin{array}{l}\text { No. of specimens } \\
\text { xamined }\end{array}$ & $\begin{array}{l}\text { No. of samples used } \\
\text { for DNA sequence }\end{array}$ & Haplotypes \\
\hline $0-1$ & Susuya shell mound (Sakhalin, Okhotsk) & 22 & 16 & $\begin{array}{l}\text { M1, M5, M5, M5, M5, M5, M5, M5, } \\
\text { M5, M5, M5, A5, A7, A10, A10, A11 }\end{array}$ \\
\hline $0-2$ & Musashi-wan site (Paramushir island, Okhotsk) & 1 & 1 & M10 \\
\hline $0-3$ & Sensyu-to site (Shumshu island, Okhotsk) & 2 & 2 & $\mathrm{M} 10, \mathrm{~A} 13$ \\
\hline $0-4$ & Tosamuporo shell mound (Hokkaido, Okhotsk) & 1 & 1 & M5 \\
\hline $0-5$ & Bentenjima shell mound (Hokkaido, Okhotsk) & 4 & 4 & M5, M5, M5, A1 \\
\hline $0-6$ & Hamanaka site (Rebun island, Okhotsk) & 5 & 5 & M5, M5, M10, A5, A7 \\
\hline $\mathrm{J}-7$ & Hakodate-shinai shell mound (Hokkaido, Jomon) & 1 & 1 & M5 \\
\hline $\mathrm{J}-8$ & Korekawa shell mound (Aomori, Latest Jomon) & 1 & 1 & M2 \\
\hline J-9 & Obora shell mound (Iwate, Latest Jomon) & 3 & 3 & M2, M5, A3 \\
\hline $\mathrm{J}-10$ & Monzen shell mound (Iwate, Middle-Late Jomon) & 1 & 1 & M2 \\
\hline $\mathrm{J}-11$ & Tagara shell mound (Miyagi, Late Jomon) & 27 & 10 & $\begin{array}{l}\text { M5, M5, A2, A2, A2, } \\
\text { A2, A3, A6, A6, A6 }\end{array}$ \\
\hline $\mathrm{J}-12$ & Hosoura shell mound (Miyagi, Jomon) & 1 & 1 & $\mathrm{~A} 2$ \\
\hline $\mathrm{J}-13$ & Satohama shell mound (Miyagi, Latest Jomon) & 1 & 0 & \\
\hline $\mathrm{J}-14$ & Maehama shell mound (Miyagi, Late Jomon) & 1 & 0 & \\
\hline $\mathrm{J}-15$ & Anezakidai shell mound (Chiba, Late Jomon) & 2 & 2 & M2, M5 \\
\hline $\mathrm{J}-16$ & Yahagi shell mound (Chiba, Late-Latest Jomon) & 1 & 0 & \\
\hline $\mathrm{J}-17$ & Kasori shell mound (Chiba, Middle-Late Jomon) & 1 & 1 & A6 \\
\hline $\mathrm{J}-18$ & Ubayama shell mound (Chiba, Middle-Late Jomon) & 1 & 0 & \\
\hline $\mathrm{J}-19$ & Sugita shell mound (Kanagawa, Middle-Latest Jomon) & 1 & 1 & M2 \\
\hline $\mathrm{J}-20$ & Hirai shell mound (Aichi, Latest Jomon) & 2 & 2 & $\mathrm{M} 2, \mathrm{M} 2$ \\
\hline $\mathrm{J}-21$ & Yoshigo shell mound (Aichi, Latest Jomon) & 4 & 0 & \\
\hline $\mathrm{J}-22$ & Ikawazu shell mound (Aichi, Latest Jomon) & 2 & 2 & $\mathrm{~A} 3, \mathrm{~A} 3$ \\
\hline $\mathrm{J}-23$ & Hobi shell mound (Aichi, Latest Jomon) & 1 & 1 & M2 \\
\hline $\mathrm{Y}-24$ & Asahi site (Aichi, Yayoi) & 5 & 2 & A9, A12 \\
\hline $\mathrm{J}-25$ & Hashima shell mound (Okayama, Middle Jomon) & 1 & 1 & M2 \\
\hline $\mathrm{J}-26$ & Tsugumo shell mound (Okayama, Late-Latest Jomon) & 1 & 0 & \\
\hline $\mathrm{C}-27$ & Kusadosengen site (Hiroshima, Kamakura) & 21 & 9 & $\begin{array}{l}\text { M2, M2, M2, M2, M2, } \\
\text { M11, M11, M11, M11 }\end{array}$ \\
\hline $\mathrm{Y}-28$ & Harunotsuji site (Iki island, Yayoi) & 29 & 5 & $\mathrm{M} 2, \mathrm{M} 2, \mathrm{M} 2, \mathrm{~A} 4, \mathrm{~A} 4$ \\
\hline K-29 & Daimon shell mound (Magasaki, Kofun) & 1 & 1 & A8 \\
\hline \multirow[t]{2}{*}{$\mathrm{J}-30$} & Todoroki shell mound (Kumamoto, Early-Late Jomon) & 1 & 1 & A14 \\
\hline & Total & 145 & 74 & \\
\hline
\end{tabular}

3,000 r.p.m. for 10 minutes. The supernatant was removed, and the pellet of bone powder was repeatedly decalcified with $10 \mathrm{ml}$ of $0.5 \mathrm{M}$ EDTA. After the decalcification, the bone powder sample was treated overnight in $5 \mathrm{ml}$ of $0.5 \mathrm{M}$ EDTA with proteinase $\mathrm{K}(300 \mu \mathrm{g} / \mathrm{ml})$ and $\mathrm{N}$-lauryl sarcosine $(0.5 \%)$ (Hardy and others, 1995, with slight modifications). The sample was centrifuged at 3,000 r.p.m. for 10 minutes, and then the supernatant containing the ancient DNA was extracted twice with phenol, once with chloroform: phenol (1:1) and once with chloroform to remove the protein. The supernatant 
was concentrated using a Centricon 30 micro-concentrator (Amicon, Beverly, MA) and was washed with distilled water. These treatments concentrated the DNA samples to a final volume of about 20-100 $\mu \mathrm{l}$. The extracted DNA samples were directly used for PCR tests. The DNA extracts were independently prepared two or three times to verify the results.

Precautions were taken to prevent contamination of the DNA from modern dogs. For example, we always handled the specimens with gloved hands, all reagents were autoclaved 90 mins, disposable sterile containers and filter pipette tips were used, all reagents and implements were under ultraviolet irradiation when they were not in use to inactivate DNAs from other origins, and they were handled in a biohazard hood with a ventilation system independent from the PCR products and samples. A centrifuge rotor was used for only the ancient dog samples, and all experiments with modern dog samples were made in a different room. Reagents without bone powder were always used as controls to check for contamination in the ancient bone samples.

\section{DNA amplification by PCR}

To amplify the ancient DNA, primers mitL57: 5'-TTAAACTATTCCCTGACACCCC(8) and mitH52: 5'-TCGAGGCATGGTGATTAAG(225) were designed to amplify 258-bp of the control region. The number in parentheses is the 3' position of the corresponding sequence of the whole dog mtDNA control region (Okumura and others, 1996) and L and $\mathrm{H}$ are the light and heavy strands, respectively. The most variable control region was amplified with primers mitL57 and mitH52 in the following PCR conditions: one cycle of DNA denaturation and activation of ampliTaq Gold (Perkin Elmer, Norwalk, CT) at $95^{\circ} \mathrm{C}$ for $10 \mathrm{~min}$, annealing at $55^{\circ} \mathrm{C}$ for $1 \mathrm{~min}$, extension at $72^{\circ} \mathrm{C}$ for $1 \mathrm{~min}$, followed by 50 cycles of denaturation at $94^{\circ} \mathrm{C}$ for $30 \mathrm{sec}$, annealing at $55^{\circ} \mathrm{C}$ for $1 \mathrm{~min}$, and extension at $72^{\circ} \mathrm{C}$ for $1 \mathrm{~min}$. When no PCR products were detected in the 50 cycles of PCR, a seminested PCR strategy was usually used. The second PCR was made with primers mitH52 and mitL63: 5'-ACCCCTACATTCATATATTGAAT(26), and $1 \mu 1$ of the first PCR products, for 30 cycles under the same PCR conditions. As a result, 198-bp of the variable region amplified by seminested PCR was used to analyze their haplotypes. After PCR amplification, the product was checked by electrophoresis through $1.5 \%$ agarose gel, and the primers were removed using a Centricon 100 micro-concentrator (Amicon). Then 1-5 $\mu \mathrm{l}$ of the concentrated PCR product was used for direct sequencing.

\section{DNA sequencing and phylogenetic analysis}

The amplified modern and ancient DNA fragments were directly sequenced using a 373S DNA Sequencer and a Taq DyeDeoxy Terminator Cycle Sequencing Kit (Applied Biosystems Inc., Foster City, CA). The DNA sequence data were analyzed using GENETYX-MAC software (Software Development Co., LTD., Tokyo) for multiple sequence alignment. Phylogenetic analysis was performed using the Phylip program package, version 3.5c (Felsenstein, 1993). The mean numbers of nucleotide substitutions 
per nucleotide site between sequences were calculated using the two-parameter method (Kimura, 1980). A dendrogram was made using the unweighted pair-group method with the arithmetic mean (UPGMA) method, and the neighbor-joining (NJ) method (Saitou and Nei, 1987) from the estimated distance matrices. To determine the confidence intervals of the phylogenies, the bootstrap method was used from 1,000 replications.

\section{Results \\ Quality of specimens and DNA amplification}

All the DNA was extracted from 145 specimens and was used to amplify the ancient mtDNA. Amplification of the DNA using the PCR was successful in 74 samples (Table 1). In general, the samples from the shell mounds were good to amplify the DNA because their compact bones were well preserved. Moreover, little PCR inhibitor, known as fluorescent materials inhibiting the PCR reaction (Pääbo, 1989; Tuross, 1994), was in these samples. The ancient dog specimens from archaeological sites other than shell mounds, especially from the Harunotsuji site (Yayoi Period), contained a large amount of PCR inhibitor, but the PCR reactions were successful for several samples (5 of 29, Table 1). The amplification of ancient DNA appeared to be markedly correlated with the degree of preservation of the archaeological specimens. For example, DNA amplification produced good results with hard and less coloured specimens.

\section{DNA sequence of ancient dogs}

All the DNA was extracted at least twice from the same specimens where possible, and it was amplified at least twice per DNA extract to confirm the accuracy of the DNA sequences. In the PCR experiments, samples with DNA sequences that completely matched in independent experiments were used for the phylogenetic analysis. For the 198-bp of the control region, 28 haplotypes (M1 to M28) were differentiated from modern dog DNA (Figure 1). Seventy-four ancient DNA sequences were classified into 19 types: five modern haplotypes (M1, M2, M5, M10, M11) and fourteen ancient types (A1 to A14) that were only detected within ancient Japanese dogs (Table 1, Figure 1).

Figure 2 shows a map of the mtDNA haplotypes amplified from archaeological sites. Haplotype M5 was widely distributed in the northern part of Japan including Hokkaido Island and Sakhalin, while haplotype M2 was widely distributed in the southern part of Japan. The south border line (Anezakidai shell mound, Location J-15) for the distribution of haplotype M5 is in the middle of Honshu Island near Tokyo, while the north border line (Korekawa shell mound, Location J-8) for haplotype M2 is Aomori Prefecture in the north of Honshu Island. Modern haplotypes M2 and M5 were simultaneously found in archaeological sites in the northern half of Honshu Island. Haplotype M10 was specifically obtained from three archaeological sites of the Okhotsk Period in the Kurile Islands (Locations. O-2 and O-3) and Rebun Island (Location O-6). Haplotypes A2, A3, A5 and A7 were each found from two sites near to each other, Nos. J-11, and J-12, Nos. J-9 and J-11, Nos. O-1 and O-6, Nos. O-1 and O-6, respectively, suggesting that dogs 
11111111111111111112

223334445566666777777904556677777888888991

792450492825789012345800675602357013489570

Modern dog M1 CCCACCGTCGACTCTCCCCT-AGCTTTCTATCCATTAACTGT

haplotype

M2

M3

M4

M5

M6

M7

M8

M9

M10

M11

M12

M13

M14

M15

M16

M17

M18

M19

M20

M21

M22

M2 3

M2 4

M25

M26

M27

M28

Ancient dog

haplotype

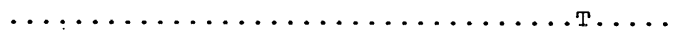

$\ldots \ldots \ldots \ldots \ldots \ldots \ldots \ldots \ldots \ldots \ldots \ldots \ldots \ldots$

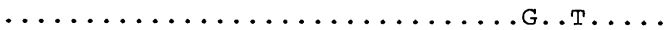

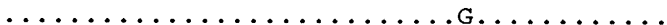

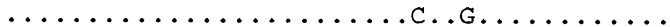

$\ldots \ldots \ldots \ldots \ldots \ldots \ldots \ldots \ldots \ldots \ldots$. . . . . AC

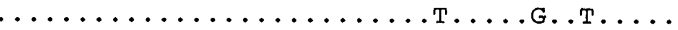

$\ldots \ldots \ldots \ldots \ldots \ldots \ldots \ldots \ldots \ldots$.

$\ldots \ldots \ldots \ldots \ldots \ldots \ldots \ldots \ldots \ldots \ldots \ldots$.

$\ldots \ldots \ldots \ldots \ldots \ldots \ldots \ldots \ldots \ldots \ldots$. . . .

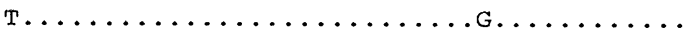

$\ldots \ldots \ldots \ldots \ldots \ldots \ldots \ldots \ldots \ldots \ldots \ldots \ldots \ldots$

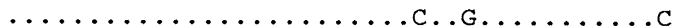

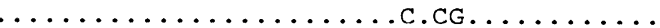

..........................

.GAT.................GC........

$\ldots$ G........ . . . . . . . . A.

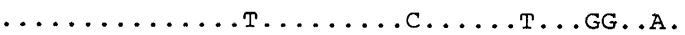

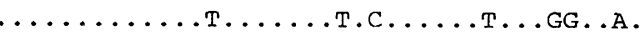

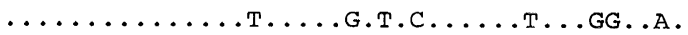

............... . ....... . . .

..........................

$\ldots \ldots \ldots \ldots \ldots \ldots \ldots \ldots \ldots$. . . . . .

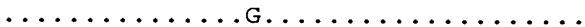

...........................

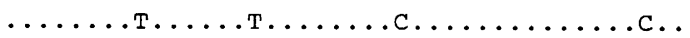

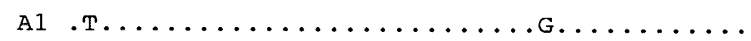

A2 $\ldots \ldots A \ldots \ldots \ldots \ldots \ldots \ldots \ldots \ldots \ldots \ldots \ldots \ldots$

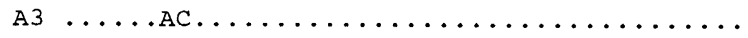

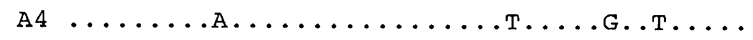

A5 $\ldots \ldots \ldots$ Tс $\ldots \ldots \ldots \ldots \ldots$. . . . .

A6 $\ldots \ldots \ldots \ldots$. . . . . . . . . . . . .

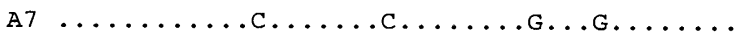

A8 $\ldots \ldots \ldots \ldots \ldots \ldots \ldots \ldots \ldots \ldots \ldots$. . . .

A9 $\ldots \ldots \ldots \ldots \ldots \ldots$. . . . . . . . .

A10 $\ldots \ldots \ldots \ldots \ldots \ldots \ldots \ldots \ldots \ldots \ldots \ldots$

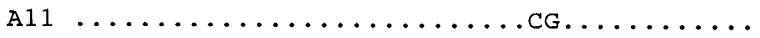

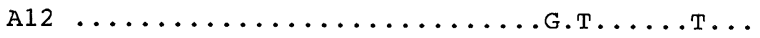

A13 $\ldots \ldots \ldots \ldots \ldots \ldots \ldots \ldots \ldots \ldots \ldots \ldots \ldots \ldots \ldots$. . . .

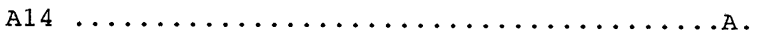

Figure 1 Base substitutions and gaps found in the forty-two different haplotypes of 198 base pairs of the control region in modern and ancient Japanese dogs. Their identities are shown by dots. Nucleotide position 1 corresponds to the base position 27 described by Okumura and others (1996) of the whole dog mtDNA control region. 
migrated frequently. The other eleven haplotypes, M1, M11, A1, A4, A8, A9, A10, A11, A12, A13 and A14 were from dogs found at one site, indicating that these dogs showed a unique genetic marker and were distributed only in a restricted region.

Among the haplotypes from archaeological specimens, five haplotypes, A2, A3, A6, A14 and M5, were from at least one archaeological site of the Jomon Period, but they were not seen at sites of other periods. An exception is the M5 haplotype of the Okhotsk Period. From the dogs examined in this study, native dogs in the Jomon Period (the

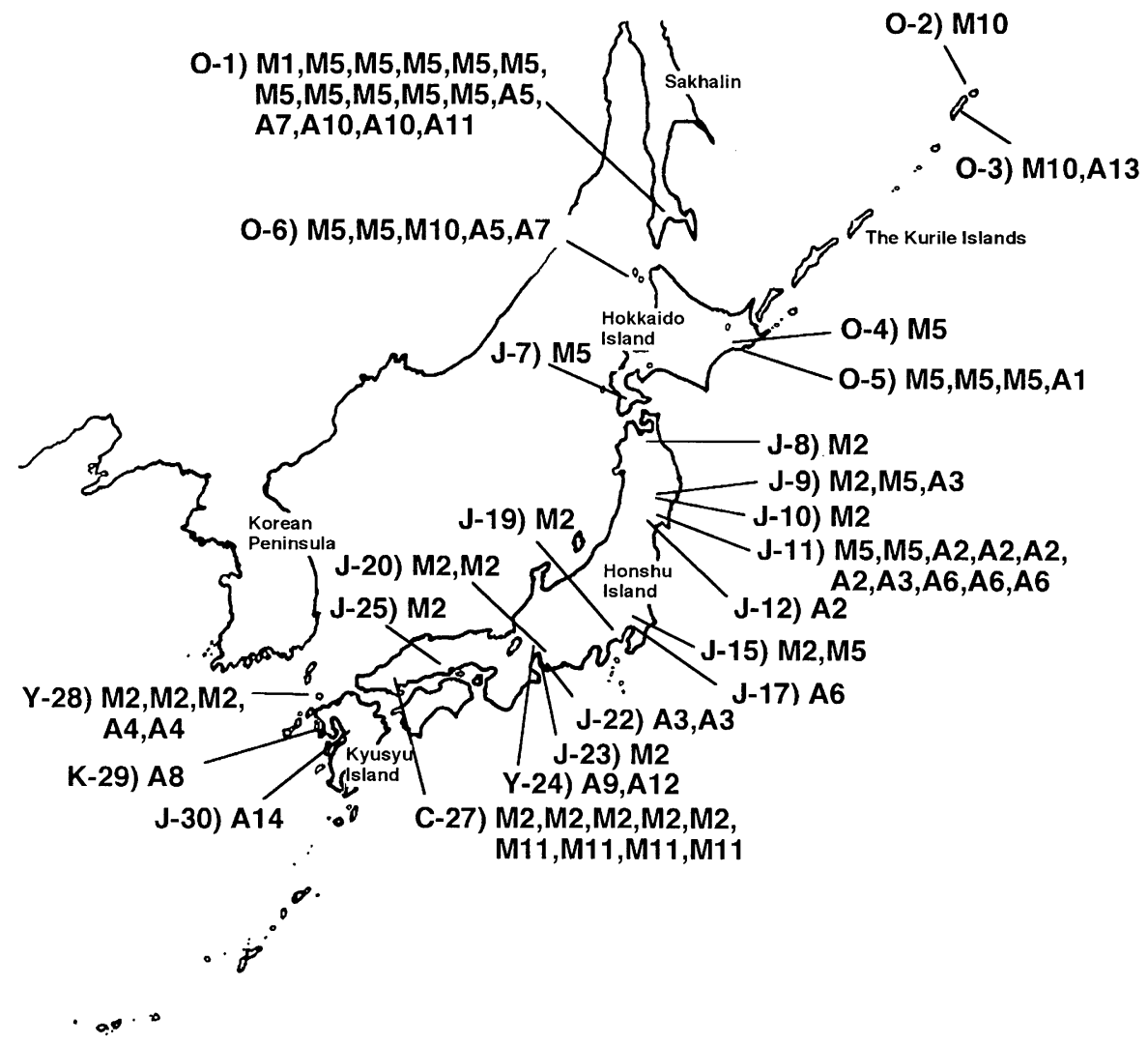

Figure 2 Haplotypes and isolation sites of ancient dog amplified DNA sequences. Locations and names in Okhotsk Period: O-1) Susuya shell mound, O-2) Musashi-wan site, O-3) Senshu site, O-4) Tosamuporo shell mound, O-5) Bentenjima shell mound, O-6) Hamanaka site; in Jomon Period: J-7) Hakodate-shinai shell mound, J-8) Korekawa shell mound, J-9) Obora shell mound, J-10) Monzen shell mound, 11) Tagara shell mound, J-12) Hosoura shell mound, J-15) Anezakidai shell mound, J-17) Kasori shell mound, J-19) Sugita shell mound, J-20) Hirai shell mound, J-22) Ikawazu shell mound, J-23) Hobi shell mound, J-25) Hashima shell mound, J-30) Todoroki shell mound; in Yayoi Period: Y-24) Asahi site Y-28) Harunotsuji site; in Kofun Period: K-29) Daimon shell mound; in Kamakura Period: C-27) Kusadosengen site. Symbols by the site number (see Table 1) are the mtDNA haplotypes detected from each archaeological site. 
oldest archaeological period studied) had already some genetic diversity. Haplotypes A4, A8 and M11 were only detected in dogs from the Harunotsuji site (Yayoi Period), Daimon shell mound (Kofun Period) and Kusadosengen site (Kamakura Period), respectively. Haplotypes A1, A5, A7, A10, A11, A13, M1 and M10 were seen in dogs from archaeological sites of the Okhotsk Period. Haplotype M2 was detected in samples from all periods from the Jomon to Kamakura, indicating that the dog population with haplotype M2 was well established in Japan since the Jomon Period.

Phylogenetic analysis of ancient $m t D N A$ and a comparison with mtDNA from modern Japanese dog breeds

To estimate the nucleotide variation of ancient DNA, we constructed a new phylogenetic tree using a total 178 DNA samples of the 198-bp control region by UPGMA. The branching pattern within the $\mathrm{C} 1$ and $\mathrm{C} 4$ lineages of the UPGMA tree somewhat differed from the UPGMA tree of the full control region sequences from 94 modern dogs (Okumura and others, 1996), but retained the same four lineages (data not shown). A UPGMA tree was constructed from 28 modern haplotypes and 14 ancient haplotypes detected in ancient DNA samples, and all haplotypes from seventy-four ancient dogs were classified into the $\mathrm{C} 1$ lineage (Table 2). A neighbor-joining (NJ) tree was also constructed from 28 modern haplotypes and 14 ancient haplotypes (Figure 3 ). Three major clusters (CL1, CL2 and CL3) were detected in the NJ tree. The cluster CL1 contained a distinct subcluster CL1a (M17 and M18), corresponding to the C3 lineage of the UPGMA tree. The CL1 cluster comprised 20 modern dog haplotypes and all haplotypes from ancient dogs. No ancient haplotype was detected in clusters CL2 and CL3.

Table 2 shows the relationship between haplotypes from ancient dog samples and modern Japanese dog breeds. Haplotype M1 from dog samples from the Okhotsk Period was detected in three modern Japanese breeds (Shiba, Akita and Kishu). Haplotype M2 found in dogs from the Korekawa, Obora, Monzen, Anezakidai, Sugita, Hirai, Hobi and Hashima shell mounds, and the Harunotsuji and Kusadosengen archaeological sites was widely detected in six modern Japanese native dogs (Shiba, Akita, Hokkaido, Iki, Kai and Ryukyu), showing that the M2 haplotype is the most common haplotype. Haplotype M5 from the northern sites of Honshu Island (Obora, Tagara and Anezakidai), Hokkaido Island (Tosamuporo, Bentenjima and Hakodate), Rebun Island (Hamanaka) and Sakhalin (Susuya) was detected only in the modern Ryukyu dog and the Shetland Sheep dog. This haplotype is rare in modern dog breeds. Haplotype M11 detected in dogs from the Kusadosengen archaeological site was observed in modern Kishu and Shiba Japanese native dogs, and Haplotype M10 from archaeological sites of the Okhotsk Period was detected in modern Akita and Shiba dog breeds. The haplotypes of ancient dogs in the Jomon Period showed two modern haplotypes (M2 and M5), and four unique haplotypes (A2, A3, A6 and A14) not observed in modern dogs. Because haplotype M2 included most of the Japanese native dog breeds (Table 2), identifying exactly the ancient 
Table 2 Correlation of the haplotypes and modern Japanese dog breeds

\begin{tabular}{|c|c|c|c|c|c|}
\hline \multirow{2}{*}{$\begin{array}{l}\text { Cluster } \\
\text { in NJ } \\
\text { (Lineage)* }^{*}\end{array}$} & \multirow{2}{*}{ Haplotype } & \multirow{2}{*}{$\begin{array}{l}\text { Modern Japanese } \\
\text { dog breeds }\end{array}$} & \multicolumn{2}{|c|}{ No. of modern dogs } & \multirow{2}{*}{$\begin{array}{c}\text { Archaeological Periods } \\
\text { of ancient dogs } \\
\text { (No. of specimens) }\end{array}$} \\
\hline & & & $\begin{array}{c}\text { Japanese } \\
\text { breeds }\end{array}$ & $\begin{array}{c}\text { Non-Japanese } \\
\text { breeds }\end{array}$ & \\
\hline \multirow{18}{*}{$\begin{array}{l}\text { CL1 } \\
\text { (C1) }\end{array}$} & M1 & Shiba, Akita, Kishu & 8 & 4 & Okhotsk (1) \\
\hline & M2 & $\begin{array}{l}\text { Shiba, Akita, Hokkaido } \\
\text { Iki, Kai, Ryukyu }\end{array}$ & 20 & 9 & $\begin{array}{l}\text { Jomon (9), Yayoi (3), } \\
\text { Kamakura (5) }\end{array}$ \\
\hline & M3 & & & 1 & \\
\hline & M4 & Shiba, Iki, Akita & 20 & & \\
\hline & M5 & Ryukyu & 1 & 1 & Jomon (5), Okhotsk (16) \\
\hline & M6 & $\begin{array}{l}\text { Shiba, Akita, Hokkaido } \\
\text { Kishu, Shikoku }\end{array}$ & 12 & 7 & \\
\hline & M7 & Ryukyu, Shiba & 3 & & \\
\hline & M8 & Shiba & 2 & & \\
\hline & M9 & Shiba & 1 & & \\
\hline & M10 & Akita, Shiba & 3 & 1 & Okhotsk (3) \\
\hline & M11 & Kishu, Shiba & 3 & & Kamakura (4) \\
\hline & M12 & Iki, Shiba & 4 & 2 & \\
\hline & M13 & & & 1 & \\
\hline & M14 & Kishu & 1 & & \\
\hline & M15 & & & 4 & \\
\hline & M24 & & & 1 & \\
\hline & M25 & Shiba & 1 & 1 & \\
\hline & M28 & & 1 & & \\
\hline CL1a & M17 & & & 2 & \\
\hline (C3) & M18 & Kishu & 1 & & \\
\hline CL2 & M16 & Shiba, Shikoku, Ryukyu, Akita & 20 & 2 & \\
\hline (C2) & M27 & Shiba & & 1 & \\
\hline CL3 & M19 & Akita & 1 & & \\
\hline \multirow[t]{5}{*}{ (C4) } & M20 & Ryukyu, Shiba & 4 & 19 & \\
\hline & M21 & Kishu, Ryukyu & 2 & & \\
\hline & M22 & Akita, Hokkaido, Iki & 10 & & \\
\hline & M23 & Shiba & 3 & & \\
\hline & M26 & & & 1 & \\
\hline \multirow{14}{*}{$\begin{array}{l}\text { Ancient } \\
\text { dog }\end{array}$} & A1 & & & & Okhotsk (1) \\
\hline & A2 & & & & Jomon (5) \\
\hline & A3 & & & & Jomon (4) \\
\hline & A4 & & & & Yayoi (2) \\
\hline & A5 & & & & Okhotsk (2) \\
\hline & A6 & & & & Jomon (4) \\
\hline & A7 & & & & Okhotsk (2) \\
\hline & A8 & & & & Kofun (1) \\
\hline & A9 & & & & Yayoi (1) \\
\hline & A10 & & & & Okhotsk (2) \\
\hline & A11 & & & & Okhotsk (1) \\
\hline & A12 & & & & Yayoi (1) \\
\hline & A13 & & & & Okhotsk (1) \\
\hline & A14 & & & & Jomon (1) \\
\hline Total & & & 121 & 57 & 74 \\
\hline
\end{tabular}

*The clusters in NJ correspond to UPGMA lineages. 


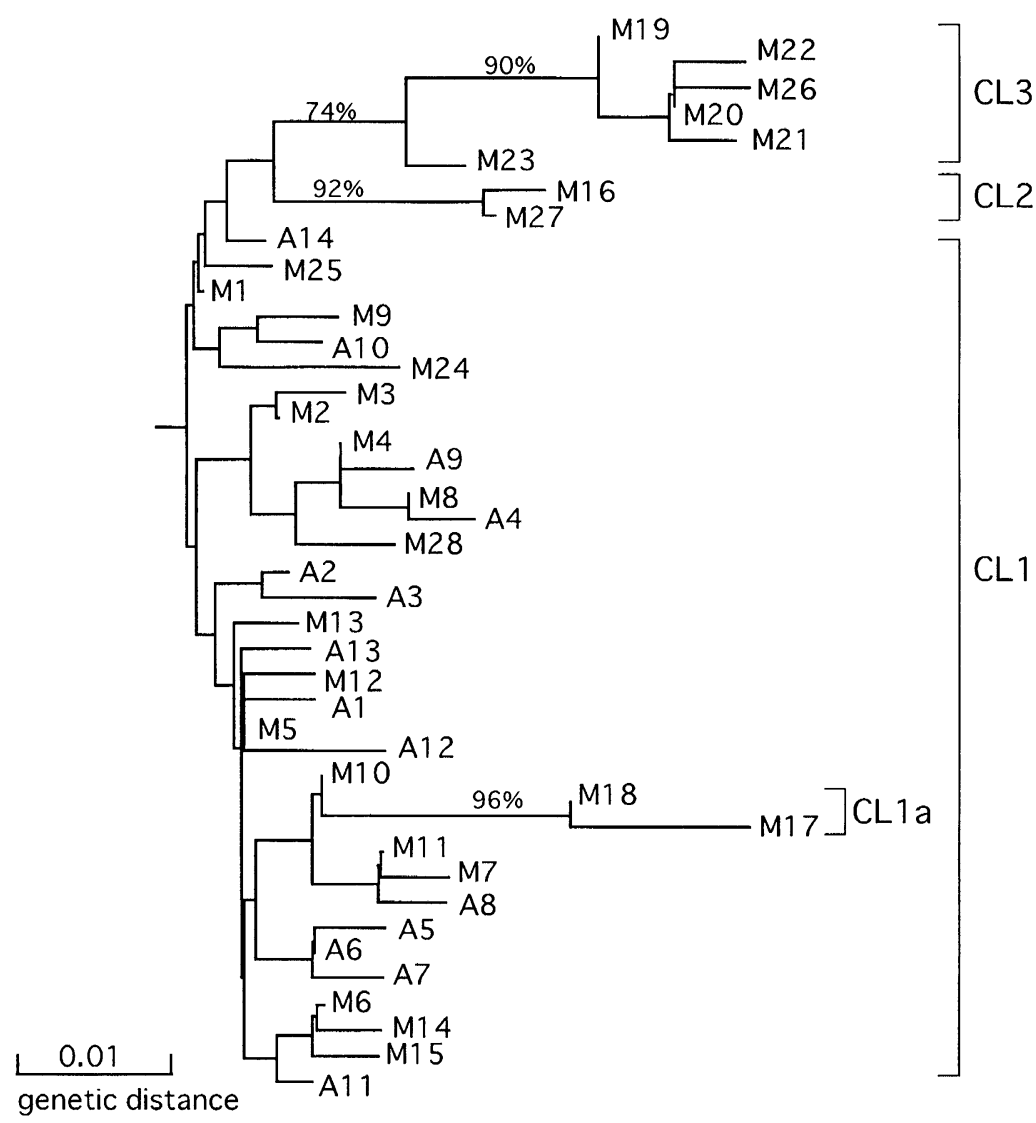

Figure 3 The NJ tree drawn from indices of the nucleotide substitution per site calculated by Kimura 2-parameter method among 28 modern and 14 ancient dog mtDNA sequences. Designation of each haplotype follows Figure 1. Numbers on the branch indicate bootstrap values $(\%, 1000$ replicates). The tree topology showed major three distinct clusters (CL1 containing a subcluster CL1a, CL2 and CL3).

Japanese dog breed from its haplotype was difficult.

\section{Discussion}

In this study, we attempted to amplify ancient mtDNA from 145 ancient dog specimens from archaeological sites of the Jomon, Yayoi, Kofun, Kamakura and Okhotsk Periods. From 74 (51\%) of $145 \mathrm{dog}$ specimens, the 198-bp ancient mtDNA was amplified using seminested PCR. Ancient dog specimens (29 out 37 sample: $78 \%$ ) from the Okhotsk period revealed the highest DNA isolation frequency among dog specimens obtained from the five historical periods (Jomon, Yayoi, Kofun, Kamakura and Okhotsk Periods). Because the dog specimens from the Okhotsk Period are the latest samples and they were preserved in sandy soil near the Okhotsk Sea, little PCR inhibitor remained in 
them.

Haplotypes M2 and M5 have a unique geographic distribution. The distribution pattern of haplotype M2 resembles the distribution pattern of the mtDNA haplotype of the mouse Mus musculus musculus found in the southern two-thirds of Japan, whereas the distribution pattern of haplotype M5 resembles that of the mtDNA haplotype of $M . \mathrm{m}$. castaneus found in the north of Japan (Yonekawa and others, 1988). The border line between the two subspecies of mouse is in Fukushima Prefecture at about $250 \mathrm{~km}$ north of Tokyo. A dual structure model was made for the history of the Japanese human population that shows that modern Japanese people were established by immigration and colonization in the Yayoi Period from central China and that the aboriginal Japanese (Jomon people) came from Southwest Asia or southern China (Hanihara, 1991). Following this model for humans, Yonekawa and others (1988) speculated that M. m. castaneus first migrated to Japan with the aboriginal Japanese and spread all over the Japanese archipelago. Later, $M$. m. musculus invaded Japan with new human immigrants and drove the aboriginal $M . m$. castaneus to the northern region of Japan. The distribution of human hepatitis B virus (Nishioka, 1981), adult T-cell leukemia (Ishida and Hinuma, 1986), and mtDNA analyses of humans (Horai and others, 1991) is consistent with this model. If this model is adapted to the geographic distribution of ancient dogs in this study, haplotype M5 may be one original type of the Japanese dog and haplotype M2 is a newcomer population. However, showing that the haplotype M2 dog was brought by immigrants is difficult, because haplotype M2 is widely seen in dogs of the Jomon Period. However, haplotype M5 might have been brought by immigrants through the northern route from Sakhalin to Hokkaido and Honshu. The geographic distribution of haplotypes of ancient dogs may suggest useful anthropological information about the human population history of the Japanese, because dogs would always have migrated with man.

Tanabe and others (1991) made an extensive survey of the 25 blood protein loci from 2,959 individual dogs of 40 breeds or local populations and found a geographical cline in allelic variations, such as hemoglobin, ganglioside monooxygenase, erythrocyte glucose phosphate isomerase and plasma postalbumin-3. The gene of high $\mathrm{K}(\mathrm{HK})$ red blood cells is found in the dogs of Korean peninsula and Japanese archipelago except for Kyushu Island, but not in indigenous dogs from Taiwan, Indonesia, Mongolia and Sakhalin (Fujise and others, 1997). From archeological evidence of the skull morphology (Nishimoto, 1989; Shigehara, 1989) and the incidence of tongue spots (Ota, 1980; Tanabe 1996) of various modern Japanese dog breeds, Tanabe $(1991,1996)$ suggested that the origin of modern Japanese dogs was established by crossbreeding two main lineages: an older dog population (before or within the Jomon Period) brought from southeast Asia, and a newcomer population brought from the Asian mainland through the Korean peninsula in the Yayoi and Kofun Periods. From a morphological investigation of skulls, ancient dogs in the Jomon Period are generally characterized by small body size, like the Shiba breed, slightly different from those found in the Yayoi and Kofun Periods (Nishimoto, 1989; Shigehara, 1989). Shigehara (1994) reported that the size change of 
the original Japanese dogs was already completed by the Kamakura Period, because few marked changes occurred between the end of the Kamakura Period and the Edo Period (1600-1900 A.D.). This study suggests that the native dog population in the Jomon Period belonged to the same lineage (probably the CL1 cluster in NJ) from DNA analysis, as well as from samples from the Kofun (Daimon shell mound), Yayoi (Harunotsuji and Asahi archaeological sites) and Kamakura (Kusadosengen archaeological site) Periods (Figure 3). The haplotype M11 dogs from the Kusadosengen archaeological site may be a new haplotype brought to Japan after the Yayoi Period. The appearance of new haplotypes found in the archaeological sites later than the Jomon or Yayoi Periods suggest that trade, including that of dogs, between Japan and foreign countries was extremely active.

Although the samples were small and the sampling sites were limited, the dog breeds belonging to the CL1 cluster were widely distributed in the Japanese archipelago in the Jomon Period. Particularly, two haplotypes M2 and M5 distributed in southern and northern Japan, respectively, in the Jomon Period, likely contributed to formation of modern Japanese dog lineages as a genetic ancestor. Network analysis using 28 modern and 14 ancient haplotypes suggests that haplotypes M1 and M5 may be a common ancestor for modern dog haplotypes, including 14 ancient haplotypes detected in this study (data not shown) If so, knowing when the dogs belonging to the CL2 and CL3 clusters first came to Japan and how they participated in the formation of the gene composition of the modern dog populations is of interest. The numbers of Japanese native dogs have sharply declined in Japan since World War II. Most modern dog breeds are now commercially bred by dog breeders using breeding systems with small numbers of dogs to maintain the purity of the breeds. For example, the CL2 cluster contains 9 Shiba dogs showing the same haplotype among the 13 dogs (Okumura and others, 1996). The gene composition of modern dog populations may be affected by these modern breeding systems. Possibly certain lineages of a small number of dogs raised for several years would have been artifically bred, leading to large dog populations.

In this study, the native dog population in the Jomon Period appears to belong to the CL1 cluster. However, to trace precisely the migration route of ancient Japanese dogs, DNA sequences should be examined from ancient dog specimens in neighbouring countries. Further molecular investigations of ancient dogs collected from many archaeological sites in different periods as well as investigations of the male-specific genes encoded on the $\mathrm{Y}$ chromosome are needed to estimate the formation process and the paternal transmission of the genes during the formation of the modern Japanese dog lineages.

\section{Acknowlegement}

We would like to thank Dr. Takeru Akazawa, University Museum, University of Tokyo, for allowing us to study Hasebe's dog collection. We are grateful to Dr. Hiroshi Abe, Tohoku Historical Museum, to Dr. Kenji Miyakoshi, the Department of Education, Aichi prefecture, and to Dr. Kazuaki Soejima, the Department of Education, Nagasaki 
prefecture, who gave us the chance to study ancient dog specimens. This work was supported by a Grant-in-Aid (Nos. 04101001 and 09208102) from the Ministry of Education, Science and Culture, Japan, and by the Sasagawa Scientific Research Grant from The Japan Science Society (8-208).

\section{REFERENCES}

Clutton-Brock J. (1995) Origins of the dog: domestication and early history. In Serpell J. ed., "The domestic, its evolution, behavior and interactions with people", Cambridge University Press, Cambridge, pp. 7-20.

Cooper A., Mourer-Chauvire C., Chambers G.K., von Haeseler A., Wilson A.C., and Pääbo S. (1992) Independent origins of the New Zealand moas and kiwis. Proceeding of National Academy of Sciences of USA, vol. 89, pp. 8741-8744.

Felsenstein J. (1993) PHYLIP version 3.5c Executables for Macintosh.

Fujise H., Higa K., Nakayama T., Wada K., Ochiai H., and Tanabe Y. (1997) Incidence of dogs possessing red blood cells with high $\mathrm{K}$ in Japan and east Asia. Journal of Veterinary Medical Science, vol. 59, pp. 495-497.

Hagelberg E. and Clegg J.B. (1993) Genetic polymorphisms in prehistoric Pacific islands determined by analysis of ancient bone DNA. Philosophical transactions of the Royal Society of London. Ser. B, Biological Sciences, vol. 252, pp. 163-170.

Hanihara K. (1991) Dual structure model of the polulation history of the Japanese. Japan Review, vol. 2, pp. 1-33.

Hardy C., Callou C., Vigne J.D., Casane D., Dennebouy N., Mounolou J.C., and Monnerot M. (1995) Rabbit mitochondrial DNA diversity from prehistoric to modern times. Journal of Molecular Evolution, vol. 40, pp. 227-237.

Hemmer H. (1990) The origins of domestic animals; the dog, In, "Domestication; the decline of environmental appreciation”, Cambridge University Press, Cambridge, pp. 38-44.

Higuchi R., Wrischnik L.A., Oakes E., George M., Tong B., and Wilson A.C. (1987) Mitochondrial DNA of the extinct quagga: relatedness and extent of postmortem change. Journal of Molecular Evolution, vol. 25, 283-287.

Horai S., Kondo R., Murayama K., Hayashi S., Koike H., and Nakai N. (1991) Phylogenetic affiliation of ancient and contemporary humans inferred from mitochondrial DNA. Philosophical transactions of the Royal Society of London, Ser. B, Biological Sciences, vol. 233, pp. 409-417.

Ishida T. and Hinuma Y. (1986) The origin of Japanese HTLV-1. Nature, vol. 322, pp. 504.

Kimura M. (1980) A simple method for estimating evolutionary rate of base substitutions through comparative studies of nucleotide sequence. Journal of Molecular Evolution, vol. 16, pp. 111-120.

Nishimoto T. (1989) Animal remains in Shimoguri Kuwanae Iseki. Report on Cultural Assets of Oita Prefecture, vol. 80, pp. 48-61 (In Japanese). 
Nishioka K. (1981) Natural history of hepatitis B virus and human beings. Proceedings of Japan Academy, vol. 38, pp. 1-19 (In Japanese with English summary).

Okumura N., Ishiguro N., Nakano M., Matsui A., and Sahara M. (1996) Intra- and interbreed genetic variations of mitochondrial DNA major noncoding regions in Japanese native dog breeds (Canis familiaris). Animal Genetics, vol. 27, pp. 397-405.

Oota H., Saitou N., Matsushita T., and Ueda S. (1995) A genetic study of 2,000-year-old human remains from Japan using mitochondrial DNA sequences. American Journal of Physical Anthropology, vol. 98, pp. 133-145.

Ota K. (1980) The dog, its domestication and development, with special reference to the origin of the Japanese native dog (a review). Report of the Society for Researches on Native Livestock, vol. 9, pp. 53-94.

Pääbo S. (1989) Ancient DNA: extraction, characterization, molecular cloning, and enzymatic amplification. Proceedings of National Academy of Sciences of the USA, vol. 86, pp. 1939-1943.

Saitou N. and Nei M. (1987) The neighbor-joining method: A new method for reconstructing phylogenetic trees. Molecular Biology and Evolution, vol. 4, pp. 406-425.

Scott J.P. and Fuller J.L. (1965) Dog hehavior: the genetic bases. The University of Chicago Press, Chicago.

Shigehara N. (1989) Morphological changes in ancient Japanese dogs. Archeological Journal, vol. 303, pp. 22-27 (In Japanese).

Shigehara N. (1994) Morphological changes in Japanese ancient dogs. Archaeozoologia vol. VI/2, pp. 79-94.

Stone A.C. and Stoneking M. (1993) Ancient DNA from a pre-columbian amerindian population. American Journal of Physical Anthropology, vol. 92, pp. 463-471.

Tanabe Y. (1991) The origin of Japanese dogs and their association with Japanese people. Zoological Science, vol. 8, pp. 639-651.

Tanabe Y. (1996) Roots and genealogy of Japanese dog. Journal of the Japan Veterinary Medical Association, vol. 49, pp. 221-226.

Thomas R.H., Schaffner, W., Wilson, A.C., and Pääbo, S. (1989) DNA phylogeny of the extinct marsupial wolf. Nature, vol. 340, pp. 465-467.

Tsuda K., Kikkawa Y., Yonekawa H., and Tanabe Y. (1997) Extensive interbreeding occurred among multiple matriarchal ancestors during the domestication of dog: Evidence from inter- and intraspecies polymorphisms in the D-loop region of mitochondrial DNA between dogs and wolves. Genes and Genetic Systems, vol. 72, pp. 229-238.

Tuross N. (1994) The biochemistry of ancient DNA in bone. Experientia, vol. 50, pp. 530-535.

Vilà C., Savolainen P., Maldonado J.E., Amorim I.R., Rice J.E., Honeycutt R.L., Crandall K.A., Lundeberg J., and Wyne R.K. (1997) Multiple and ancient origins of the domestic dog. Science, vol. 276, pp. 1687-1689.

Yonekawa H., Moriwaki K., Gotoh O., Miyashita N., Matsushima Y., Shi L., Cho W.S., Zhen X.L., and Tagashira Y. (1988) Hybrid origin of Japanese mice "Mus musculus 
molossinus". Evidence from restriction analysis of mitochondrial DNA. Molecular Biology and Evolution, vol. 5, pp. 63-78.

Handling editor: Saitou Naruya 